\title{
A COMPARISON STUDY OF THE REGISTRATION SYSTEM OF TRADEMARKS IN INDONESIA AND AUSTRALIA
}

\author{
Agung Sudjatmiko \\ Private Law Departement, Faculty of \\ Law, \\ Airlanga University \\ agung.sujatmiko@fh.unair.ac.id
}

\author{
Ria Setyawati (Author) \\ Private Law Departement, Faculty of \\ Law, \\ Airlanga University ria \\ riasetyawati@fh.uniar.ac.id
}

\begin{abstract}
Trade Mark as a part of Intellectual Property Rights (IPR) has very important function in goods trade, especially for products with famous trade mark. The famous trade mark has high economic value if it is compares to others products. On the other side, it is also fragile to falsification which done by irresponsible business person. Due to the protection trademarks owners in Indonesia, the law maker compile Indonesian Trademarks Act Number 20 Year 2016 regarding Trade Marks and Geographical Indication. Under Law Number 20 Year 2016, the protection is not only for typical goods and or services, but also untypical goods and or services. Similarly in Australian Trademarks Act 1995. In both Act (Indonesian and Australian act) the registration must be done by the owner of the trade mark. The protection for any infringement of trade marks is not automatically, the registration for any Trade Mark is a must. In this matter, non-registered trademarks is not be protected. There are some reasons why the trademarks owners do not registering their trademarks, such as the lack of knowledge about the importance of registered trademarks and they think that the registration is costly and need times to get the certificates of registered trademarks. In fact, registration is cheap and easy to do it. When the owner can not register by himself/hersel, he or she can ask to the consultant of Intellectual Property Rights. Consultant is a person who has expertise in intellectual property rights. Indonesian and Australian Trade Mark Act also adopt priority right system regarding the registration. The priority right give some benefits for applicants who want to register their trademarks, such as they can saving time and cost for registration fee. There are two system in registering trademarks, constitutive system and declarative systems. Indonesian Trade Marks Act 1961 used declarative system, but it turn in to constitutive system in Trade Mark Act 1992, Trade Mark Act 1997, Trade Mark Act 2001, and the newest, Trade Mark Act 2016. This article will analyze the constitutive system of trademarks registration in the Indonesian Trademarks Act and Australian Trade Marks Act. It will
\end{abstract}

be focussed on the benefits of constitutive system in both countries.

Keywords----Intellectual Property Rights, Trade Mark, Constitutive System.

\section{INTRODUCTION}

As part of intellectual property rights (IPR), trade mark has special things that can be distinguish with others rights in IPR regime. Such privileges tend to be monopolies that include the rights to use the mark concerned and the right to grant permission to others to use it. According to Article 1 number 1 of Law no. 20 of 2016 regarding Trademarks and Geographical Indications (hereinafter referred to as Law 20/2016). the so-called brand sign that can be displayed graphically in the form of pictures, logos, names, words, letters, numbers, arrangement of colors, in the form of 2 (two) dimensions and / or 3 (three) dimensions, sound, hologram, or combination of 2 (two) or more of such elements to distinguish goods and / or services produced by a person or legal entity in the goods and / or service trade activities. Trademarks rights, according to Article 1 Number 5 of Law. $20 / 2016$ is an exclusive right granted by the state to the registered trademark owners for a certain period of time by using the Mark itself or permitting others to use it.

Under these provisions, the grant of a special right shall be granted by the state. In other words, to obtain such a special right must pass through the application of registration to the country and its registration shall be accepted. This means that the nature of the trademark registration is mandatory. Without the registration of the mark, there is no legal protection provided by the state. If a trademark is not registered in Indonesia, then there is no legal protection.

Similarly, in the Australia Trade Mark Act 1995, the protection for trademark is obtained through registration. So both the trademark legal system in Indonesia and Australia adopt constitutive system in terms of protection for trademark. The constitutive system of the trademark provide benefits for the state and the trademark owner.

\section{EXCESS FOR CONSTITUTIVE SYSTEM}

The protection for trademark in Law no. 20/2016 is adopted a constitutive system. This system affirms that the recognition and protection trademark is granted for the first 
applicant (first to file principle). The registration file for a trademark should receive by the Office of the Director General of IPR of the Department of Justice and Human Rights of the Republic of Indonesia. Constitutive system provides more legal certainty than a declarative system. The declarative system provides legal protection to the first user (first to use principle).

A declarative system is a system that give protection for the first user of the trademark concerned. This system is based on the first to use principle for the protection of trademark. If a a trademark is registered, the registration does not entitle rights, but the presumption only. If a dispute arises, about who the first user is, it must be proven in Court.

The declarative system was adopted in Law no. 21 / 1961. Article 2 paragraph (1) of Law no. 21/1961 states:

The special right to use a trademark to distinguish the goods of a company or commercial goods of a person or an entity from another person's goods is granted to any person who for the first time uses the mark for such purpose in Indonesia.

Based on the sound of the article, the special rights attached to the mark are granted the first user. Anyone who can prove that he is the first user of a trademark will get legal protection. According to Soerjatin, the first user this does not mean that the brand is already worn by someone else wear it, but already used before the opponent wear it. [1] So the starting point is if there is a brand dispute, then both parties should be able to prove in front of the court who among them is the first user.

Even though Law no. 21/1961 embraces the declarative system (first to use principle), it has accommodated about the registration of the trademark. As contained in the General Explanation of Law no. 21/1961 which asserts, the special right to use a trademark under this Act is based on the first use of the trademark. As the first user of a trademark is considered the person who registered the trademark for the first time, unless it is proved that the other person is the first true user of the trademark. It's just that someone who has registered his brand is not necessarily deemed to be entitled to use the trademark forever, because if anyone else can prove that he / she is the first owner of the same trademark with the registered mark, then the person registering the mark will first be void to use the brand.

Implementation of the declarative system in Indonesia characterized by a person or entity that obtains the right and legal protection of a trademark not only the person or body that uses the first time, but is required to have good faith in his registration. Decision of the Supreme Court of the Republic of Indonesia of December 13, 1972 Number: 677K / Sip / 1972 in the Tancho brand case, where the first registration of the Tancho brand by Wong A Kiong was annulled by the Supreme Court under the lawsuit of PT. Tancho Indonesia Co. Ltd. In its legal considerations, the Supreme Court deliver the opinion that Tancho's registration by Wong A Kiong proves to be the first user of malicious intent, because it mimics the brand used first in the Indonesian territory by PT. Tancho Indonesia Co. Ltd., and trades goods fraudulently as if the goods being traded came from abroad.

According to Yahya Harahap, Law no. 21/1961 contains the conception of dualism, on the one hand using the first to file principle, who the first registrant of a brand is deemed to have a superior right from the owner of another person's brand, but on the other hand also deliver the first to use principle.[2] According to Bambang Sulistyobudi it can cause difficulties in proving against who the first owner actually, thus causing legal uncertainty.[3]

Based on that fact, then in Law No.19 / 1992, Law no. 14/1997, Law No.15 / 2001 and Law no. 20/2016 regarding trademark, declarative system is not used anymore and replaced with constitutive system. The use of such constitutive system in trademark laws also complies with the requirements contained in the TRIPs agreement. The provisions in the TRIPs referring to the use of the constitutive system are contained in Article 18 which reads "Initial registration, and each renewal of registration, of a trademark shall be for a term no less than seven years. The registration of a trademark shall be renewable indefinitely ". The provisions of the article clearly state that in essence only registered marks are protected.

The development of the use of the constitutive system is increasingly evident by its inclusion in the Model Law for Developing Countries on Marks, Trade Names and Acts of Unfair Competition, which in Article 4 it is explained that the exclusive right of a brand will be obtained through a registration.

Yahya Harahap states that the constitutive system has advantages, namely:

1. Legal certainty to determine who owner of the trademark. It is stated as the first filling date or registered in DUM:

2. Legal certainty of proof because it is only based on the fact of registration

3. To realize the legal suspicion of who is the owner of the most eligible brand, does not cause controversy between the first user and the first registrant, since the alleged law stands only on the fact of the first registrant;

4. Because the basis for determining who the most important brand holders are is based on the principle of the first registrant, and the proof is based on an authentic document, to withdraw the allegations of the law, much simpler than the declarative system. This has a positive impact on the settlement of the dispute, ie a much simpler, quicker and less costly settlement.

In addition to these advantages, the constitutive system also provides a source of revenue in the state of registration fees. These registration fees will be the source of the state in generating revenues that are very beneficial to the sustainability of development. Trademark registration fee according to the provisions applicable to Small and Medium Micro Enterprises (MSME) of Rp. 600.000, - while non UMKM Rp. 1,000,000, -

On the basis of several advantages and advantages contained in the constitutive system, then in UUM, the system used is a constitutive system. It is affirmed in Article 3 of Law no. 20/2016 stating, "The right to a Mark is obtained after the Mark is registered".

What is contained in Article 3 of Law no. 20/2016 it basically confirms that only registered trademark owners will be 
granted exclusive rights from the State. The grant of exclusive rights is nothing but legal recognition and protection to the legally registered trademark owner in the General Register of Marks at the Office of the Directorate General of HKI of the Department of Law and Human Rights of the Republic of Indonesia. Therefore, in order for a brand to be protected by law, it must be registered, so the nature of registration is compulsory.

\section{TRADEMARK REGISTRATION IN INDONESIA ANDAUSTRALIA}

The rights of trademark is granted by the state on the basis of registration. The right does not arise automatically, but must be applied to the state through registration. Therefore, anyone who wants to get the rights of a trademark must apply for registration. Registration of trademark is mandatory, if not registered, no rights will arise. Applications for registration of rights to a trademark, in addition to meeting the formal and material requirements as stipulated in Articles 20 and 21 of Law no. 20/2016, also must meet other requirements as stipulated in Article 4-8 of Law no. 20/2016 on Terms and Procedures of Application. The terms are as follows:

Article 4 Number (1): Application for registration of Mark shall be filed by the Petitioner or his Attorney to the Minister electronically or non-electronically in the Indonesian language. (2) In the Application as referred to in paragraph (1) shall include: a. date, month, and year of Application; b. full name, citizenship, and address of the Applicant; c. full name and proxy address if the Application is filed by a Proxy; $d$. color if the mark applied for registration uses the color element; e. the country's name and date of the first Trademark request in the event that the Application is filed with Priority Right; and f. class of goods and / or classes of services as well as a description of the type of goods and / or types of services. (3) The application is signed by the Applicant or his Attorney. (4) The application as referred to in paragraph (1) shall be attached with the Brand label and proof of payment of fee. (5) The cost of a Trademark registration application shall be determined per class of goods and / or services. (6) In the case of a Mark referred to in paragraph (4) in the form of 3 (three) dimensions, the Brand label is enclosed in the characteristic form of the Mark. (7) In the case of a Mark referred to in paragraph (4) in the form of votes, the Brand label attached shall be a notation and a sound recording. (8) The application as referred to in paragraph (1) shall be accompanied by a statement of ownership of the Mark which is applied for registration. (9) Further provisions concerning the Application fee as referred to in paragraph (5) shall be regulated by Government Regulation.

Article 5 (1) In the event that an Application is filed by more than one Applicant jointly entitled to the Mark, all names of the Applicant are listed by selecting one of the addresses as the Applicant's address. (2) The application as referred to in paragraph (1) shall be signed by one of the Petitioners entitled to the Mark by enclosing the written approval of the Petitioners representing. (3) The application as referred to in paragraph (1) in which one of the applicants or more foreign citizens and foreign legal entities domiciled abroad shall be filed by a proxy. (4) In the event that the Application as referred to in paragraph (1) is filed by its
Attorney, the power of attorney for it shall be signed by all parties entitled to such Marks.

Article 6 (1) application for more than 1 (one) class of goods and / or services may be filed in one Application. (2) The application as referred to in paragraph (1) shall state the type of goods and / or services included in the class applied for registration. (3) Further provisions on the class of goods and / or services as referred to in paragraph (1) shall be regulated by a Ministerial Regulation.

Article 7 (1) Applications and matters relating to the administration of Marks filed by an applicant residing or domiciled outside the territory of the Unitary State of the Republic of Indonesia shall be filed by a Proxy. (2) The applicant as referred to in paragraph (1) shall declare and choose the address of the Proxy as the legal domicile in Indonesia.

Article 8 Further provisions concerning the Terms and Procedures of Application as referred to in Article 4 through Article 6 shall be regulated by a Ministerial Regulation.

The provision of Article 4-8 of the 20/2016 Law confirms the matters relating to the procedural registration of the rights to the mark, particularly regarding the identity of the applicant as the person entitled to the right of the mark when the registration is received. If the Petitioner resides or is permanently located outside the territory of the Republic of Indonesia, shall be submitted through his / her proxy in Indonesia. Such Applicant shall declare and elect a power of residence as his legal domicile in Indonesia.

In article 27, paragraph 1 (b) of the Australia Trade Mark Act 1995, it is stipulated on ownership claims which are evidence of ownership of a trademark namely:

(i). That the aplicant is using or intends to use the mark in relation to the goods or services;

(ii). That the aplicant has authorized or intends to authorise another's use of the mark in relation to the goods or services; or

(iii). That the aplicant intends to assign the trademark to a corporate body that company of the trademark in relation to the goods or services

If the application for registration using priority rights must be submitted within six (6) months from the date of receipt of the first Trademark registration application received in another country, which is a member of the Paris Convention for the Protection of the Industrial Property or member of the Establishing Agreement the World Trade Organization. The purpose of registration by using this priority right is to facilitate registration by saving the cost and time of registration.

Similar provisions are also found in the Australia Trade Mark Act 1995 which outlines:

Application claiming convention claiming convention priority in Australia shall be filed in Australia within 6 months of the filing of the priority application upon which the convention claim is made. No extensions of this dead line are available. However, as long as the Australian application is filed within the six month period, the convention claims on the application may be made within two days of filing the Australian application. This period is also extendable. 
After the procedure is performed, then the Directorate General shall check the completeness of the registration requirements of the Marks. If there is any deficiency in the completeness of the requirements, the shortfall must be met within a period of 2 (two) months from the date of dispatch of the request letter to meet the completeness of the requirements. If the completeness cannot be fulfilled within a maximum period of two months, the application shall be deemed withdrawn by notice from the Directorate General.

If all requirements have been fulfilled, the application get the date of receipt. The date of acceptance shall serve as the date of the filling date. The date become important for entry into force of the registration. The long process for trademark registration pursuing the date of receipt of the registration as the effective date of the rights to the trademark. The protection for the trademark started from the date of receipt.

Upon receipt of the complete application, within 30 (thirty) days from that date, the Directorate General shall conduct a substantive examination. This substantive examination relates to the examination of the mark relating to the formal and material requirements as set forth in Articles 4, 5 and 6 of the UUM. The examination shall be performed and completed within a period of 9 (nine) months. Subtative examination conducted by functional examiner apparatus working in Directorate General of HKI. The inspector is a professional officer in his field according to his expertise appointed and dismissed by the Minister.

If the Examiner reports the results of a substantive examination that the application may be approved for registration, upon approval by the Directorate General, the Application is announced in the Official Gazette (BRM), but if the Examiner reports the results of the substantive inspection that the application cannot be registered or rejected, it shall be notified in writing to the Applicant or his proxy by stating the reason. Applicants or their proxies may object to the results of such substantive examination within a period of 30 (thirty) days at the latest from the date of notification. If the applicant does not submit an objection, the Directorate General shall decide on the rejection of the Application. On the other hand, if the applicant or his proxy submits an objection or response, and the objection or response is acceptable, the request is announced in the Official Gazette (BRM), but if the objection or response is unacceptable, a decision will be issued regarding the refusal of the Application. The denial decision is notified in writing to the applicant or his proxy by stating the reason.

Against the approved application to be registered, the Application is subsequently announced in the Official Gazette of Brands (BRM) or special facilities that are easily and clearly visible to the public. The announcement lasted three months. The announcement was made in order to give the other party a chance to file an objection. The liability basically means that the relevant brand cannot be registered and should be rejected. If there is an objection, the objection is submitted to the Applicant or his / her proxy. Furthermore, the applicant or his / her proxy shall be entitled to file an objection against the objection he or she receives. Such denunciation shall be submitted in writing to the Directorate General no later than two (2) months from the date of receipt.

The Office of the Director General of IPR shall use the objection and rebuttal which it receives as consideration for a re-examination of the completed registration application. Reexamination is done at the latest 2 (two) months. The results of the re-examination are then given to the party who filed the objection. In the event that the objection may be accepted, the Directorate General shall notify the applicant or his proxy in writing that his application can not be registered as a mark, and to the applicant or his / her attorney may file an appeal, but if the objection is unacceptable, are listed in the General Register of Marks (DUM). Similarly, in the absence of objection from the interested parties, the Directorate General shall issue and grant the Mark Certificate to the applicant or its proxy within 30 (thirty) days from the date of expiration of the announcement period.

The Mark Certificate will be valid for ten years and may be renewable within the same time as the mark of the mark concerned is still used on the goods or services as mentioned in the Mark Certificate and the goods or services are still produced and traded. The renewal of the brand certificate is notified in writing to the owner of the Mark or its proxy and is recorded in the General Register of Marks and announced in the Official Gazette of Marks (BRM).

According to Article 41 Number (1) of Law no. 20/2016, the rights to the registered trademark may be transferred or transferred by: a. inheritance; b. will; c. waqf; d. grant; e. agreement; or $f$. other reasons justified by the provisions of legislation. As an intangible material right, the rights to a brand are equal to other material rights. Material rights over the brand may be transferred by the owner by inheritance, if the owner dies. The recipient of the right is the legitimate heir of the owner of the mark. If the rights owner of the mark does not have heirs, then the rights to the mark can be transferred to another person by way of making a will. The recipient is a recipient of the rights to the mark. The rights to a trademark may also be transferred to another party in the manner granted by the owner. The grant here means that it is given free of charge, for various purposes and purposes. Likewise, the rights to a trademark may be transferred by way of agreement, for example the right to a brand to be contracted with another party will be used as a means of repaying the debt. The latter can change over other reasons justified by legislation, such as ownership of a trademark because of the dissolution of a legal entity from the original owner of the mark, while the right to the brand is transferred to another person.

The transfer of rights to such mark must be registered at the Directorate General's Office to be recorded in the General Register of Marks (DUM), accompanied by a Certificate of Right to Mark, and then announced in the Official Gazette of Marks (BRM). If not registered, the transfer does not result in a legal effect on a third party. According to UUM's explanation, this provision aims to facilitate monitoring and realize legal certainty. If the service is concerned, the transfer must be accompanied by a guarantee of the quality of service delivery. The warranty is granted by the trademark owner or the holder of the rights to the mark or the licensee, that they will maintain the quality of the services they are trading. Such a thing is reasonable, since the service mark relates to the personal quality of the brand owner as a service provider. The quality must always be monitored and controlled, so that there is no decrease or different quality of service, which resulted to harm consumers. The transfer of right to such a registered mark is only recorded by the Directorate General, if accompanied by a written statement from the assignee that the Mark will be used for the trade in goods and or services. The 
statement is very important, because the person receiving the transfer must produce goods and or services. If not used in a product or service for three (3) consecutive years, the rights to the mark concerned may be removed from the General Register of Marks.

Procedures to be passed to obtain the right of the brand is a matter of the standard required by Law no. 20/2016. If there has been no objection from a third party, the right of the mark shall be granted to the applicant, with a term of ten years and may be renewed for another period of ten years provided that the mark is still used on the goods or services referred to in the brand certificate and the owner of the mark and / or licensee still produce goods or services. The requirement is a necessity, because lest people have a brand, but not used. The trademark certificate is subsequently a valid proof and gives rise to a monopolistic right to the owner. The owner of a brand certificate is entitled to sue anyone who uses his / her brand without his or her consent. A wide variety of brand infringement cases affecting a well-known brand are caused by other parties using the brand without permission. It happens all over the world, as in the case of a lawsuit filed by the owner of the Louis Vuitton brand in the United States, while in Indonesia, many similar cases are done to hitch another brand fame.

Registration of brand rights in Australia also contains similar terms and stages. In the Australia Trade Mark Act 1995 , the terms of the voting requirements may be registered as a trademark, such as the distinctive Harley Davidson motor sound.

Likewise, slogans are also listed as trademarks, such as Have A Break owned by Societe des Produits Nestle SA for Class 300 goods, Becaause Your Worth It, owned by L'Oreal for Class 3 goods and I'm Lovin It owned by Mc. Donalds Corporation for Classes 29, 30, 32 and 43. However, for the slogan, Law no. 20/2016 does not include it as a form of registered trademark.

\section{Conclusion}

The constitutive system in the Indonesian and Australian trademark legal system provides benefits for the brand owner in the form of legal certainty. Legal certainty is obtained because based on the existing system, ownership of brand rights is obtained through registration to the state. The State shall grant legal protection only to the right of a legally registered mark. Proof of registration in the form of a certificate provides strong evidence to its owner as a proof that can be used as a means of authentication of its trademark in case of a court dispute. The constitutive system used in the brand legal system in Indonesia and Australia not only benefits the owner, but also the state. Countries earn a profit in the form of revenue income from the cost of registering the brand. The income is very supportive for the state to finance the development and improve the welfare of the people.

\section{Reference}

[1] R. Soerjatin, Hukun Dagang I dan II, cetakan ketiga, Pradnya Paraminta, Jakarta, 1980, p.96.

[2] M. Yahya Harahap, Tinjauan Merek Secara Umum dan Hukum Merek di Indonesia Berdasarkan UU No. 19 Tahun 1992, Citra Aditya Bakti, Bandung, 1996., p.336.
[3] Bambang Sulistyobudi, Aspek Hukum Dalam Persaingan Usaha Tidak Sehat Atas Hak Merek (Khusus Kemasan Merek), Tesis, Magister Hukum Universitas Diponegoro, Semarang, 2003 ,

p. 79. 
